\title{
Sponge species from ports of the inner and middle parts of İzmir Bay (Aegean Sea, Eastern Mediterranean)
}

\section{İzmir iç ve orta körfezi limanlarından sünger türleri (Ege Denizi, Doğu Akdeniz)}

\author{
Alper Evcen ${ }^{1^{*}}$ • Melih Ertan Çınar² \\ 'Ege University, Faculty of Fisheries, Department of Hydrobiology, 35100, Bornova, İmir, Turkey \\ https://orcid.org/0000-0003-1134-255 \\ ${ }^{2}$ Ege University, Faculty of Fisheries, Department of Hydrobiology, 35100, Bornova, Izmir, Turkey \\ https://orcid.org/0000-0002-1802-2801 \\ Corresponding author: alperevcen@gmail.com \\ Received date: 10.10 .2019 \\ Accepted date: 06.12 .2019

\section{How to cite this paper:} \\ Evcen, A. \& Çınar, M.E. (2020). Sponge species from ports of the inner and middle parts of İzmir Bay (Aegean Sea, Eastern Mediterranean). Ege Journal of \\ Fisheries and Aquatic Sciences, 37(2), 149-155. DOI: 10.12714/egejfas.37.2.05
}

Abstract: Within a surveillance programme for the detection of invasive alien species, many benthic samples were randomly collected from several ports located in the inner and middle parts of Izmir Bay. A total of four sponge species (Sycon raphanus, Sycon ciliatum, Paraleucilla magna and Dysidea fragilis) were found on the artificial hard substrata. Paraleucilla magna, which is being newly recorded from the Aegean coast of Turkey, is an invasive alien species and very abundant almost at all ports, covering maximally $35 \%$ of surfaces sampled. The morphological and distributional features of these species are described.

Keywords: Porifera, Demospongiae, Calcarea, Invasive Alien Species, biodiversity, distribution, Aegean Sea, Mediterranean Sea

Öz: İstilacı yabancı türlerin tespiti için yapılan bu araştırmada, İmir Körfezi'nin iç ve orta kısımlarında bulunan çeşitli limanlardan birçok bentik örnek rastgele toplanmıștır. Yapay sert substrat üzerinde toplam dört sünger türü (Sycon raphanus, Sycon ciliatum, Paraleucilla magna ve Dysidea fragilis) tespit edilmiștir. Türkiye'nin Ege kıyllarından yeni kaydedilmekte olan Paraleucilla magna, istilacı yabancı bir türdür, örneklenen yüzeylerin maksimum \% 35 'ini kaplamakta olup neredeyse tüm limanlarda bol miktarda tespit edilmiştir. Bu çalışma, bu türlerin morfolojik ve dağıım özelliklerini açıklamaktadır.

Anahtar kelimeler: Porifera, Demospongiae, Calcarea, İstilacı yabancı tür, biyoçeşitlilik, dağılım, Ege Denizi, Akdeniz

\section{INTRODUCTION}

Port environments are separated from nearby coastal systems due to the artificial structures they have and continuous shipping activities (Awad et al., 2014). Such activities make the environments more prone to invasion by alien species. It is well known that one of the main pathways for the introduction of alien species is the transport by vessels, especially in ballast waters (Carlton, 1985; Galil, 2009). However, the organism transfer by hull fouling is also widespread in the world's oceans (Bax et al., 2003). The polluted environments in ports favor the establishment of alien species of wide niche breadths. For example, on polluted hardand soft-bottoms of Alsancak and İskenderun Harbours, which are located in the eastern Mediterranean Sea, alien species (ship-mediated species in Alsancak Harbour, lessepsian invaders in İskenderun Harbour) comprised more than $70 \%$ of total zoobenthic populations (Çinar, 2006; Çinar, et al., 2006). Many alien invertebrates and fish were reported on floating docks and other artificial surfaces in ports rather than adjacent natural substrates (Glasby and Connell, 2001; Paulay et al.,
2002; Çinar et al., 2006; Perçin, 2018). Therefore, port surveys are very important for the detection and surveillance of alien species.

The Mediterranean Sea is known to be a hot spot area for the introduction of alien species as it has more than one pathway including the Suez Canal (Çinar et al., 2011). More than 900 alien species have been recorded up to date in the Mediterranean Sea (Zenetos et al., 2012). Among alien species, a total of 603 alien species have become established in the region (Zenetos et al., 2017). The majority of alien species (almost 75\%) belonging to different taxonomic groups are known from the eastern part of the Mediterranean. However, there is a lack of reliable information regarding alien sponge species in the Mediterranean (Zibrowius, 2002). Acording to Zenetos (2010) eight alien sponge species might be considered as Lessepsian species in the Mediterranean Sea. However, the presence of these species in the Mediterranean was regarded as questionable. It is now apparent that only Paraleucilla magna was considered as an 
established alien species in the Mediterranean, but its origin is still unknown (Longo et al., 2007; Zammit et al., 2009; Guardiola et al., 2011). This species was also previously reported on the natural substrata in the Sea of Marmara (Topaloğlu et al., 2016).

The present study aims to determine the diversity of sponge species inhabiting ports of İzmir Bay and to present their distributional and morphological features

\section{MATERIAL AND METHODS}

The sponge specimens were collected on artificial substrata (concrete surface, buoys, submerged ropes and tyres) at 0-3 $\mathrm{m}$ depth at 8 ports located in the inner and middle parts of Izmir Bay between March and May 2016 (Figure 1).

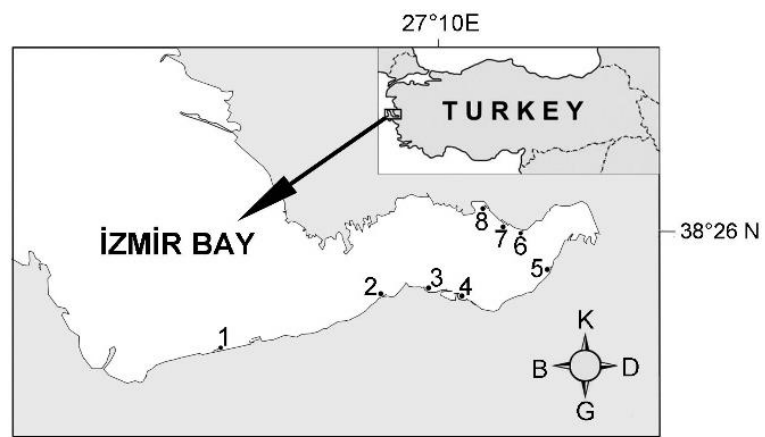

Figure 1. Locations of sampling sites: 1. Güzelbahçe Fishing Port, 2. Sahilevleri Fishing Port, 3. Inciraltı Fishing Port, 4. Levent Marina, 5. Pasaport Ferry Terminal, 6. Karşıyaka Sailing Club, 7. Karşıyaka Fishing Port, 8. Bostanlı Fishing Port

All sponges were scraped from surfaces and fixed in $4 \%$ formaldehyde. To estimate the percent coverage of Paraleucilla magna at ports, three-replicated quadrates $(25 \times$ $25 \mathrm{~cm}$ ) were put randomly on surfaces sampled. In the laboratory, all sponge specimens were washed under tap water and then transferred to vials including $70 \%$ ethanol.

For the examination of skeletal structures, skeleton preparations were made by hand dissection under a stereomicroscope. Spicule slides were prepared according to the method proposed by Klautau and Valentine (2003). A minimum of 25 spicules of each type were measured with an ocular micrometer. Some specimens were dehydrated in ethanol and embedded in paraffin wax and sectioned with a microtome at various thicknesses in order to analyse the shape and size of the choanocyte chambers. The specimens identified are deposited at the Museum of the Faculty of Fisheries, Ege University (ESFM).

\section{RESULTS}

Examination of sponge specimens collected from the ports of Izmir Bay yielded a total of 4 sponge species (Sycon raphanus, S. ciliatum, Paraleucilla magna and Dysidea fragilis) belonging to 3 families (Sycettidae, Amphoriscidae and
Dysideidae) and 2 classes (Calcarea and Demospongiae). The invasive alien species $P$. magna, which is being recorded for the first time from the Aegean coast of Turkey, was found in all ports with high percent coverages.

\section{Class: CALCAREA Bowerbank, 1864 Family: Sycettidae Dendy, 1893 Sycon ciliatum (Fabricius, 1780) (Figure 2)}

Spongia ciliata Fabricius ,1780: 448. Sycandra ciliata; Haeckel, 1870: 296, pls. 151, 58, 51. Sycon ciliatum; Borojevic, et al., 1968: 33.
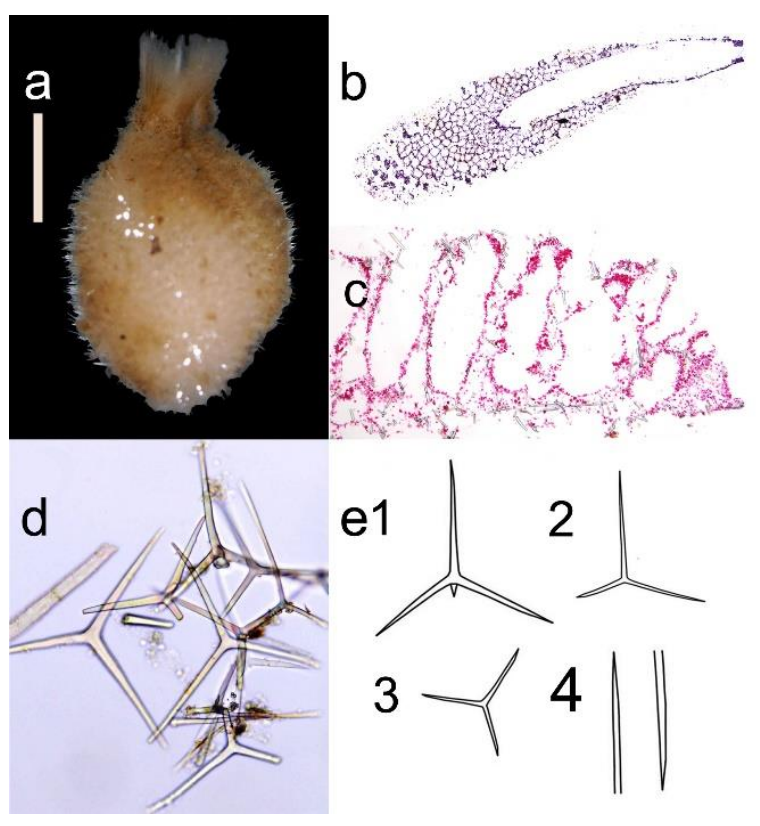

Figure 2. Sycon ciliatum. a. General view (scale: $3 \mathrm{~mm}$ ) b. Iongitudinal median section of an entire specimen (scale $3 \mathrm{~mm}$ ), c. Choanocyte chambers (scale: $100 \mu \mathrm{m}$ ), d. Overview of spicules (scale: $50 \mu \mathrm{m}$ ) e1. Subregular tetractine (scale: 40 $\mu \mathrm{m})$, e2. Large subatrial triactine (scale: $100 \mu \mathrm{m})$, e3. Small tubar triactine (scale: $120 \mu \mathrm{m}$ ), e4. Diactine (scale: $100 \mu \mathrm{m}$ ).

Material examined: ESFM-POR/2016-1, station 1, May 2016, $0.5 \mathrm{~m}$, on tyre, 8 specimens; ESFM-POR/2016-2, station 2, May 2016, $1 \mathrm{~m}$, on tyre, 6 specimens; ESFMPOR/2016-3, station 3, May 2016, $0.5 \mathrm{~m}$, on tyre, 18 specimens.

Description: Living members of this species have a soft consistency. The body is vase-shaped. Specimens high $2.5 \mathrm{~cm}$ diameter up to $0.8 \mathrm{~cm}$ wide. The terminal large osculum is surrounded by a fringe of long stiff diactines (Figure 2a). The surface is hairy. In addition, spicules are visible on the surface of body. Specimens have a short stalk. Specimens are usually solitary or occur in small groups. Colour is grey, white and occasionally brown in life and in ethanol. The aquiferous system is syconoid (Figure 2b). The choanocyte chambers are 
partially cylindrical (100-220 $\mu \mathrm{m})$, entirely free from each other (Figure 2c). The skeleton consists of tiractines, tetractines and diactines (Figure 2d). The atrial skeleton is composed of sagittal triactines and tetractines. Subregular tetractines (basal actines: $40-80 \times 8-10 \mu \mathrm{m}$, apical actines: $50-110 \times 9-12 \mu \mathrm{m})$ are regularly overlapping in the atrial skeleton. Actines are slightly conical and sharp (Figure 2, e1). Subatrial skeleton consists of brushes of larger triactines. Actines are slightly conical and sharp. The paired actines are straight or slightly curved. The unpaired actine is frequently longer than the paired ones (paired actines: 100-220 X 5-12 $\mu \mathrm{m}$, unpaired actines: 90-260 $\mu \mathrm{m}$ X 8-16 $\mu \mathrm{m}$ ) (Figure 2, e2). The tubar skeleton consists of small triactines with long and thin diactines. Triactines is subregular to sagittal (paired actines: 80-120 x 4$8 \mu \mathrm{m}$ unpaired actines: $90-140 \times 5-10 \mu \mathrm{m})$. Diactines are sharp and slightly curved (900-2800 x 6-20 $\mu \mathrm{m}$ ) (Figure 2, e3e4).

Habitat and Distribution: It is a common species in the shallow sublittoral zone, rarely in depths of more than $150 \mathrm{~m}$, in the Mediterranean, the Atlantic and the Arctic (Longo and Pronzato, 2011; Van Soest et al., 2017b; Rapp, 2013). Along the coasts of Turkey, this species was previously reported from the Sea of Marmara by Ostroumoff $(1894 ; 1896)$ and Topaloğlu et al., (2016).

\section{Sycon raphanus Schmidt, 1862 (Figure 3)}

Sycon raphanus Schmidt, 1862: 14-15, pl. i, Figure 2; Burton, 1956: 115; Tsurnamal, 1975: 146, Figure 4.

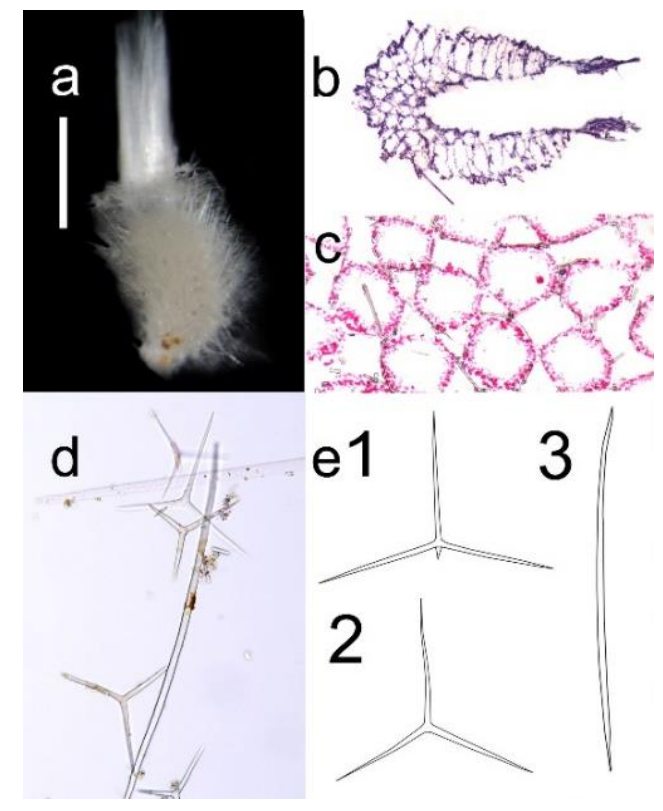

Figure 3. Sycon raphanus. a. General view (scale: $2 \mathrm{~mm}$ ), b. longitudinal median section of an entire specimen (scale $2.5 \mathrm{~mm}$ ), c. Choanocyte chambers (scale: $100 \mu \mathrm{m}$ ) d. Overview of spicules $(200 \mu \mathrm{m})$, e1.Atrial tetractines (scale: $60 \mu \mathrm{m}$ ), e2. Tubar triactines (scale: $100 \mu \mathrm{m}$ ), e3. Diactine (scale: $300 \mu \mathrm{m}$ )
Material examined: ESFM-POR/2016-4, station 1, May 2016, $1 \mathrm{~m}$, on tyre, 8 specimens; ESFM-POR/2016-5, station 2, May 2016, 0-1 m, on tyre, 6 specimens.

Description: Alive specimens of this species have a fragile tissue. Color is white in life and in ethanol. Specimens have globular or tube in shaping up to $0.9 \mathrm{~cm}$ high and $0.5 \mathrm{~cm}$ wide with short stalk. Numerous diactines on the surface make it very hispid (Figure 3a). Specimens are usually solitary or occur in small groups. The aquiferous system is syconoid and the atrium is central (Figure $3 b$ ). The choanocyte chambers (range from $60-150 \mu \mathrm{m}$ ) are almost fused in the distal cone (Figure $3 c)$. The skeleton consists of triactines, tetractines and diactines (Figure $3 \mathrm{~d}$ ). Tubar skeleton and distal cones are composed of triactines with slightly curved paired actines (paired actines 90-180 X 10-12 $\mu$ m and unpaired actines 150$250 \times 10-12 \mu \mathrm{m})$ and diactines. The atrial skeleton is composed of subregular to regular (rarely sagittal) tetractines and triactines. Tetractines of the atrial skeleton are similar to triactines. (apical actines 55-90 x 6-10 $\mu \mathrm{m}$, basal actines 100 $210 \times 8-12 \mu \mathrm{m}$ ) (Figure 3, e1, e2). Diactines are slightly curved (900-2800 x 20-25 $\mu \mathrm{m}$ ) (Figure 3e, 3).

Habitat and Distribution: This species is very common in the shallow water benthic habitats of the Mediterranean Sea and the eastern Atlantic coasts. It occasionally occurs in depths down to $300 \mathrm{~m}$ depth (Longo and Pronzato, 2011; Van Soest et al., 2017b). It was previously reported from the coasts of Turkey, except for the Black Sea coast (Topaloğlu and Evcen 2014).

Family: Amphoriscidae Dendy, 1893 Paraleucilla magna Klautau, Monteiro \& Borojevic, 2004 (Figure 4,5)

Paraleucilla magna Klautau et al., 2004: 1-8, Figure 2 (a-c); Longo et al., 2007: 1749-1755, Figure 2-5; Topaloğlu et al., 2016: 54, Figure 3.

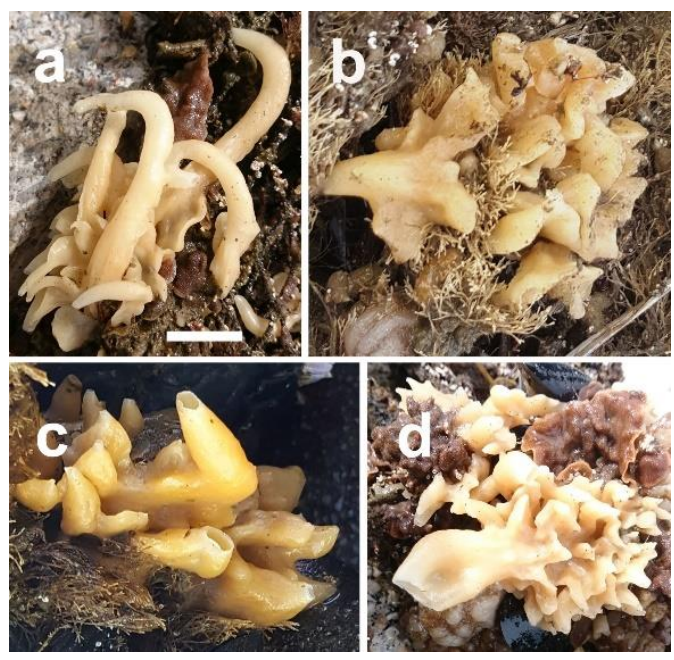

Figure 4. Different morphologies of Paraleucilla magna in İzmir Bay. Scale bar: $a=2 \mathrm{~cm}, b=2.5 \mathrm{~cm}, c=4 \mathrm{~cm}, d=4 \mathrm{~cm}$ 


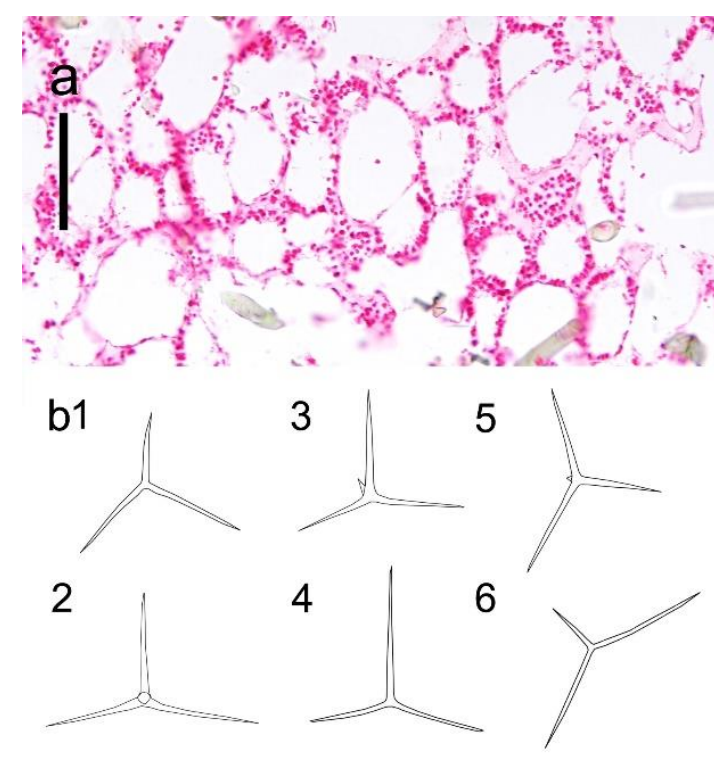

Figure 5. Cross section through the choanocyte chamber of $P$. magna (scale: $120 \mu \mathrm{m}$ ), b. Spicules, b1. Cortical triactine (scale $300 \mu \mathrm{m})$, b2, 3. Cortical tetractine (scale: $320 \mu \mathrm{m}$ ), b4. Subatrial triactine (scale: $200 \mu \mathrm{m}$ ), b5. Subatrial tetractine (scale: $300 \mu \mathrm{m}$ ), b6. Atrial triactine (scale: $150 \mu \mathrm{m}$ ).

Material examined: ESFM-POR/2016-6, station 1, March 2016, $0.3 \mathrm{~m}$, on tyres, 4 specimens; ESFM-POR/2016-7, station 2, March 2016, 0.3-1 m, on tyres and concrete walls (particularly on Mytilus galloprovincialis Lamarck, 1819), 13 specimens; ESFM-POR/2016-8, station 3, March 2016, 0.5 m, on used tyre and buoys, 3 specimens; ESFM-POR/2016-9, station 4, March 2016, $0.3 \mathrm{~m}$, on tyres, buoys and walls, 15 specimens; ESFM-POR/2016-10, station 5, March 2016, 1-3 $\mathrm{m}$, on rope, 2 specimens; ESFM-POR/2016-11, station 6, April 2016, $1 \mathrm{~m}$, on rope and tyres, 3 specimens; ESFMPOR/2016-12, station 7, April 2016, $0.5 \mathrm{~m}$, on tyre, 2 specimens; ESFM-POR/2016-012, station 8, April 2016, 0.3 $\mathrm{m}$ on tyres and buoys, 3 specimens.

Additional material examined: ESFM-POR/2004-02, identified as Porifera (sp.), Izmir Bay, June 2004, 1 specimen.

Description: It is massive, thickly encrusting body. Consistency of living specimens is a friable and very fragile. Color is cream or light brown in life and white in ethanol. The specimens show different morphological features, but they are usually massive or tubular structure reaching a height of 10 $15 \mathrm{~cm}$ (Figure 4). The oscules are terminal on erect tubes, 10 $15 \mathrm{~mm}$ in diameter. The surface is smooth.

The aquiferous system is leuconoid and the atrium is large. Choanocyte chambers are spherical and sub-spherical, ranging from 60 to $110 \mu \mathrm{m}$ (Figure 5a). Skeleton is inarticulate, consisting of triactines and tetractines. Cortical triactines can be equiangular, but usually sagittal with paired and unpaired actines (cortical triactines paired actines 180-560 $\mu \mathrm{m}$ and unpaired ones $190-580 \mu \mathrm{m}$, thickness of the actine at its base 10-40 $\mu \mathrm{m}$ (Figure 5, b1). Cortical tetractines are equiangular; their apical actin is longer than basal actines (length of the apical actine 300-810 $\mu \mathrm{m}$ (mean $265 \mu \mathrm{m}$ ) and basal ones 180$600 \mu \mathrm{m}$, thickness of the actine at its base 16-45 $\mu \mathrm{m}$ (Figure 5 , b2, b3). Subatrial skeleton contains different kind of triactines and tetractines. Subatrial triactines usually have unpaired actines, which are longer than other actines (length of the paired ones 200-600 $\mu \mathrm{m}$ [mean $270.2 \mu \mathrm{m}$ ] and unpaired one $280-690 \mu \mathrm{m}$, thickness of the actine at its base $15-50$ (Figure 5, b4). Subatrial tetractines have apical actines shorter than others (length of the paired actines 170-600 and unpaired actine $200-610 \mu \mathrm{m}$, thickness of the actine at its base 15-50 $\mu \mathrm{m}$ (Figure 5, b5). Atrial triactines are sagittal and their unpaired actines are shorter than paired ones (length of the paired actines 180-470 $\mu \mathrm{m}$ and unpaired ones 30-180 $\mu \mathrm{m}$, thickness of the actine at its base 5-20 $\mu \mathrm{m}$.

Habitat and Distribution: This species was found at all stations in the study area. Its highest coverage (35\%) was encountered at station 2, while the lowest coverage (5-10\%) at stations 4,5 and 8 .

The invasive alien sponge Paraleucilla magna may become very abundant in eutrophic environments and shows seasonality (Longo et al., 2007). This species was originally described from the Atlantic coast of Brazil based on the specimens collected in 2001 (Klautau et al., 2004). This species was later reported from different parts of the Mediterranean Sea with its first collection dating in the area dated back to 2001 (Longo et al., 2007). This species was especially abundant on mussel farms (on rows) and artificial substrata in Mar Piccolo and Mar Grande, Taranto (North-west Ionian Sea) (Longo et al., 2007).

In addition, it abundantly occurred on other coasts of Italy (Ionian Sea, Tyrrhenian Sea and Adriatic Sea) and on the coast of Malta (Zammit et al., 2009). It was reported to have been introduced to the region by shipping (Longo et al., 2007). It was suggested that mussel farming activities were the main reason for its regional introduction (secondary introduction) within the Mediterranean Sea (Longo et al., 2007). Paralaucilla magna was also observed from the different regions in the Mediterranean Sea: Spain (Frotscher et al., 2008; Guardiola et al., 2011), Adriatic Sea Ploče harbor (Cvitković et al., 2013), Brač Island in Croatia (Klautau et al., 2016), Gulf of Olbia in Italy (Baldacconi and Trainito, 2013), Portugal, Madeira and Acores (Guardiola et al., 2016), Tivat in Montenegro (Mačić et al., 2016) and Gulf of Thessaloniki (Greece), in 2014 in a mussel farm (Gerovasileiou et al., 2017) northern Cyprus, marinas of Crete and Rhodes Island (UIman et al., 2017) and later from Marina Cap Monastir in Tunisia (Sghaier, et al., 2019).

This species was first identified as Porifera (sp. 1) along the coasts of Turkey, based on the material collected on a mussel bed (M. galloprovincialis) in June 2004 in the inner part of İzmir Bay (İnciraltı) (Çinar et al., 2008). It was later reported from natural substrata (rocks) at $10 \mathrm{~m}$ depth from the coast of Büyükada (Sea of Marmara) (Topaloğlu et al., 2016). 


\section{Class: DEMOSPONGIAE Sollas, 1885 Family: Dysideidae Gray, 1867 \\ Dysidea fragilis (Montagu, 1814) (Figure 6)}

Spongia fragilis Montagu, 1814: 114

Dysidea fragilis Manconi et al., 2013: 20, 21, Figure 9(a-c).
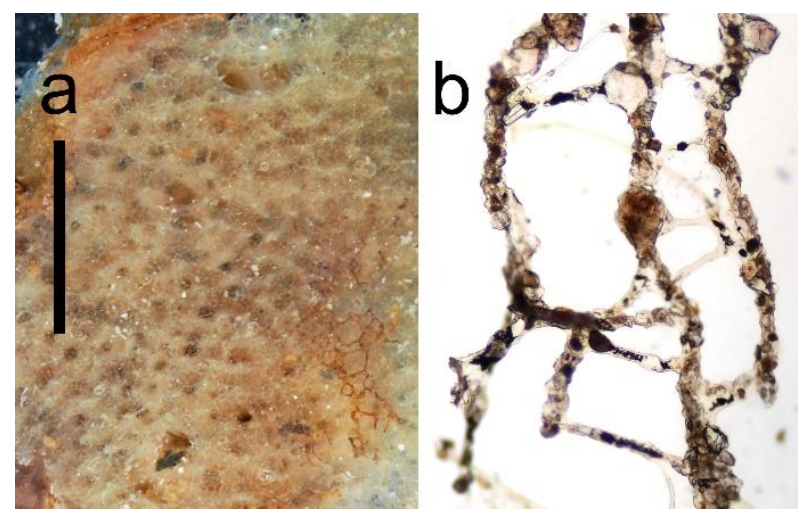

Figure 6. Dysidea fragilis. a General view of the specimen (scale: 0.4 $\mathrm{cm}$ ) with conules; $b$. The reticulate skeletal network with scanty spongin and irregular meshes of primary and secondary fibers (scale: $200 \mu \mathrm{m}$ ).

Material examined: ESFM-POR/2016-14, station 1, March 2016, $0.3 \mathrm{~m}$, on M. galloprovincialis, 1 specimen.

Description: Colour is grey to light brown in life and white in ethanol. Surface is smooth and conulose (Figure 6a). Oscules are scattered on the surface, which is up to 2-3 mm in length. Its consistency is fragile and soft. Inhalant apertures are $70-110 \mu \mathrm{m}$ in diameter. Skeleton is reticulate and extremely fragile due to scanty spongin. Primary and secondary fibers are not distinguishable from each other (50$200 \mu \mathrm{m}$ ) (Figure 6b). Spongin fibres are reticulated sometimes covered by sand grains.

Habitat and Distribution: This species is very common in the benthic habitat and Atlanto-Mediterranean taxon (Van Soest et al., 2017a). It was originally described from the British coast and wea reported in various regions and biotopes of the Mediterranean Sea between 1 and $200 \mathrm{~m}$ depth (Manconi et al., 2013). It was also reported from the coasts of Turkey, except for the Black Sea (Topaloğlu and Evcen, 2014).

\section{DISCUSSION}

Among the species found in the present study, Sycon ciliatum is very similar to $S$. raphanus in terms of its external shape: both species are ovoid and hispid with apical oscula ornate by a specular fringe. In addition, the morphology of spicules in $S$. raphanus is very close to that in S. ciliatum. This high morphological affinity between these species has caused confusion over the years. Sycon raphanus, which was originally described from the Adriatic Sea by Schmidt (1862), is characterized by having a stalk and a bulb shaped body, which are the main characters that distinguish it from the closely similar species. Afterwards, Haeckel (1872) disapproved the presence of $S$. ciliatum in the Mediterranean. According to him, all specimens identified as $S$. ciliatum in the region in fact belonged to $S$. raphanus (Klautau et al., 2016). However, Longo and Pronzato (2011) postulated that the external morphology is not a good taxonomic character to separate these two species. At the present time, histological preparation is required to distinguish these species.

Table 1. Comparative data for the dimensions of spicules (means in $\mu \mathrm{m}$ ) of the Paraleucilla magna specimens from different parts of the world

\begin{tabular}{|c|c|c|c|c|c|c|c|c|c|c|}
\hline \multirow[t]{2}{*}{ Studies } & \multicolumn{2}{|c|}{$\begin{array}{c}\text { Cortical triactine } \\
\text { (Length } \mathrm{x} \text { wide) (mean) }\end{array}$} & \multicolumn{2}{|c|}{$\begin{array}{l}\text { Cortical tetractines } \\
\text { (Length } \mathrm{x} \text { wide) } \\
\text { (mean) }\end{array}$} & \multicolumn{2}{|c|}{$\begin{array}{l}\text { Subatrial triactines } \\
\text { (Length } \mathrm{x} \text { wide) (mean) }\end{array}$} & \multicolumn{2}{|c|}{$\begin{array}{l}\text { Subatrial tetractines } \\
\text { (Length } \mathrm{x} \text { wide) }\end{array}$} & \multicolumn{2}{|c|}{$\begin{array}{l}\text { Atrial triactines } \\
\text { (Length } \mathrm{x} \text { wide) }\end{array}$} \\
\hline & Paired & Unpaired & $\begin{array}{l}\text { Basal } \\
\text { Ones }\end{array}$ & $\begin{array}{l}\text { Apical } \\
\text { Ones }\end{array}$ & Paired & Unpaired & Paired & Unpaired & Paired & Unpaired \\
\hline $\begin{array}{l}\text { Klautau et. } \\
\text { al. (2004) } \\
\text { (holotype) }\end{array}$ & $\begin{array}{l}292.8 x \\
24.0 \\
(n=30)\end{array}$ & $\begin{array}{l}289.6 x \\
24.0 \\
(n=30)\end{array}$ & $\begin{array}{l}434.4 x \\
34.4 \\
(n=30)\end{array}$ & $\begin{array}{l}468.8 x \\
31.2 \\
(n=30)\end{array}$ & $\begin{array}{l}266.4 x \\
24.0 \\
(n=25)\end{array}$ & $\begin{array}{l}358.4 x \\
25.6 \\
(n=25)\end{array}$ & $\begin{array}{l}394.4 x \\
33.6 \\
(n=30)\end{array}$ & $\begin{array}{l}338.4 x \\
31.2 \\
(n=30)\end{array}$ & $\begin{array}{l}371.2 \times 22.4 \\
(\mathrm{n}=30)\end{array}$ & $\begin{array}{l}164.0 x \\
21.6 \\
(n=30)\end{array}$ \\
\hline $\begin{array}{l}\text { Longo et al, } \\
\text { (2007) }\end{array}$ & $\begin{array}{l}374.9 x \\
27.9 \\
(n=25)\end{array}$ & $\begin{array}{l}427.9 x \\
27.9 \\
(n=25)\end{array}$ & $\begin{array}{l}388.9 x \\
36.6 \\
(n=25)\end{array}$ & $\begin{array}{l}572.1 x \\
36.6 \\
(n=25)\end{array}$ & $\begin{array}{l}399.6 x \\
35.9 \\
(n=25)\end{array}$ & $\begin{array}{l}584.1 x \\
35.9 \\
(n=25)\end{array}$ & $\begin{array}{l}344.4 x \\
30.6 \\
(n=25)\end{array}$ & $\begin{array}{l}383.6 x \\
30.6 \\
(n=25)\end{array}$ & $\begin{array}{l}236.5 \times 7.4 \\
(n=25)\end{array}$ & $\begin{array}{l}64.2 \times 7.4 \\
(n=25)\end{array}$ \\
\hline $\begin{array}{l}\text { Zammit et } \\
\text { al, (2009) }\end{array}$ & $\begin{array}{l}202.8 x \\
22.8 \\
(n=25)\end{array}$ & $\begin{array}{l}178.2 x \\
22.8 \\
(n=25)\end{array}$ & $\begin{array}{l}257.4 \mathrm{x} \\
33.6 \\
(\mathrm{n}=25)\end{array}$ & $\begin{array}{l}342.6 x \\
33.6 \\
(n=25)\end{array}$ & $\begin{array}{l}240 x \\
28.2 \\
(n=25)\end{array}$ & $\begin{array}{l}299.8 x \\
28.2 \\
(n=25)\end{array}$ & $\begin{array}{l}286.2 x \\
32.4 \\
(n=25)\end{array}$ & $\begin{array}{l}286.2 x \\
32.4 \\
(n=25)\end{array}$ & $\begin{array}{l}195.6 \times 19.8 \\
(n=25)\end{array}$ & $\begin{array}{l}91.8 \times 19.8 \\
(n=25)\end{array}$ \\
\hline This study & $\begin{array}{l}224.0 x \\
25.0 \\
(n=25)\end{array}$ & $\begin{array}{l}240.0 x \\
25.0 \\
(n=25)\end{array}$ & $\begin{array}{l}265.4 x \\
34.0 \\
(\mathrm{n}=25)\end{array}$ & $\begin{array}{l}350.8 x \\
32.8 \\
(n=25)\end{array}$ & $\begin{array}{l}270.2 x \\
30.0 \\
(n=25)\end{array}$ & $\begin{array}{l}320.4 x \\
30.2 \\
(n=25)\end{array}$ & $\begin{array}{l}310.0 x \\
31.2 \\
(n=25)\end{array}$ & $\begin{array}{l}302.0 x \\
31.2 \\
(n=25)\end{array}$ & $\begin{array}{l}200.8 \times 18.0 \\
(n=25)\end{array}$ & $\begin{array}{l}120.4 x \\
18.0 \\
(n=25)\end{array}$ \\
\hline
\end{tabular}

According to Van Soest et al. (2017b), the important difference between these species is the degree of fusion of the choanocyte chambers (radial tubes). In S. raphanus, they are almost entirely fused just up to the distal cone, while in $S$. 
ciliatum, they are entirely free from each other (Van Soest et al., 2017b). Longo and Pronzato (2011) indicated that S. raphanus occasionally has a short stalk, but all of our specimens have short stalks. In addition, S. ancora Klautau et al. (2016), which was originally described from the Adriatic Sea, resembles closely to $S$. raphanus and $S$. ciliatum, but differs from them in the shapes of the atrial triactines and the presence of anchor-like tetractines at the base (Klautau et al., 2016).

The spicule lengths of Paraleucilla magna show a similar dimension in different places (Table 1). However, the spicule lengths of our specimens are closely related to those given by Zammit et al. (2009) from the coasts of Malta. As this species exhibits a fast growing and spread potential, monitoring studies

\section{REFERENCES}

Awad, A., Haag, F., Anil, A.C. \& Abdulla, A. (2014). Guidance on Port Biological Baseline Surveys. GloBallast Monograph Series, 22, 1-48.

Baldacconi, R. \& Trainito E.. 2013. Spugne del Mediterraneo (Mediterranean Sponges). In: IL CASTELLO (Editor), Cornaredo., 128 pp.

Bax, N., Williamson, A., Aguero, M., Gonzalez, E. \& Geeves, W. (2003). Marine invasive alien species: a threat to global biodiversity. Marine Policy, 27, 313-323. DOI: 10.1016/S0308-597X(03)00041-1

Borojevic, R., Cabioch, L. \& Lévi, C. (1968). Inventaire de la faune marine de Roscoff. Spongiaires. Cahiers de Biologie Marine, 9, 1-44.

Bowerbank, J.S. (1864). A Monograph of the British Spongiadae.Volume 1. (Ray Society: London): i-xx, 1-290, pls I-XXXVII. Burton, M. (1936) The fishery grounds near Alexandria. IX. Sponges. Notes and Memoirs, Fisheries Research Directorate, Cairo 17, 1-28. DOI: 10.5962/bhl.title.56119

Burton, M. (1956). The sponges of West Africa. Atlantide Report (Scientific Results of the Danish Expedition to the Coasts of Tropical West Africa, 1945-1946, Copenhagen), 4, 111-147.

Burton, M. (1963). Revision of the classification of the calcareous sponges. British Museum (Natural History) (pp.693). London

Carlton, J.T. (1985). Transoceanic and interoceanic dispersal of coastal marine organisms: the biology of ballast water. Oceanography and Marine Biology, 23, 313-371.

Carter, H.J. (1886). Descriptions of Sponges from the Neighbourhood of Port Phillip Heads. South Australia, continued. Journal of Natural History, 18, 126-149. DOI: 10.1080/00222938609459946

Cvitković, I., M. Despalatović, I. Grubelić, V. Nikolić, B. Pleše \& A. Žuljević. (2013). Occurrence of Paraleucilla magna (Porifera: Calcarea) in the eastern Adriatic Sea. Acta adriatica, 54(1), 93-99.

Çinar, M.E. (2006). Serpulid species (Polychaeta: Serpulidae) from the Levantine coast of Turkey (eastern Mediterranean), with special emphasis on alien species. Aquatic invasions, 1, 223-240. DOI: 10.3391/ai.2006.1.4.6

Çinar, M.E., Bilecenoglu, M., Öztürk, B. \& Can, A. (2006). New records of alien species on the Levantine coast of Turkey, Aquatic invasions, 1, 84-90. DOI: 10.3391/ai.2006.1.2.6

Çinar, M.E, Katağan, T., Koçak, F., Öztürk, B., Ergen, Z., Kocatas, A., Önen, M., Kirkim, F., Bakir, K., Kurt, G., Dağli, E., Açık, Ş., Doğan, A. \& Özcan, T. (2008). Faunal assemblages of the mussel Mytilus galloprovincialis in and around Alsancak Harbour (Izmir Bay, eastern Mediterranean) with special emphasis on alien species. Journal of Marine Systems, 71, 1-17. DOI: 10.1016/j.jmarsys.2007.05.004

Çinar, M.E., Bilecenoglu, M., Öztürk, B., Katağan, T., Yokeş, M.B., Aysel, V., Dağlı, E., Açık, S., Özcan, T. \& Erdoğan, H. (2011). An updated review of alien species on the coasts of Turkey. Mediterranean Marine Science, 12, 257-315. DOI: $10.12681 / \mathrm{mms} .34$ should be impliemented to assess its impacts on the hard benthic communities prevailing inside and outside of ports in the Mediterranean Sea.

\section{ACKNOWLEDGMENT}

The authors thank Ass. Prof. Alper Doğan and Dr. Ertan Dağlı, Ms. Deniz Erdoğan-Dereli and Ms. Neslihan Türkçü, for help in collecting benthic material, and Dr. Esra Akat and Biologist İdil Yelki Öz for helping histological examination.

We also thank to Dr. Van Soest (Netherlands) and Dr. Fernanda Azevedo for their great help in providing the references and useful comments. This work is financially supported by Ege University BAP Project (Number: 16/SUF/003).

Dendy, A. (1893). Synopsis of the Australian Calcarea Heterocoela; with a proposed Classification of the Group and Descriptions of some New Genera and Species. Proceedings of the Royal Society of Victoria (New Series), 5, 69-116.

Dendy, A. (1895). Catalogue of Non-Calcareous Sponges collected by J. Bracebridge Wilson, Esq., M.A., in the neighbourhood of Port Phillip Heads. Part I. Proceedings of the Royal Society of Victoria (New Series), 7, 232-260.

Dendy, A. (1922). No. I.-Report on the Sigmatotetraxonida collected by H.M.S. "Sealark" in the Indian Ocean, Transactions of the Linnean Society of London. 2nd Series. Zoology, Volume 18, Issue 1, April 1922, Pages 1-164. DOI: 10.1111/j.1096-3642.1922.tb00547.x

Fabricius, O. (1780). Fauna Groenlandica: systematice sistens animalia Groenlandiae occidentalis hactenus indagata, quod nomen specificium. Hafniae et Lipsiae: Copenhagen, (XVI, pp 452), Denmark.

Frotscher, P.J. \& M.J. Uriz. (2008). Reproduction and life cycle of the calcarean sponge Paraleucilla magna in the Mediterranean Sea. In: XV Simposio Ibérico de Estudios de Bentos Marino, Blanes, Book of Abstracts.

Galil, B.S. (2009). Taking stock: inventory of alien species in the Mediterranean Sea. Biological Invasions, 11, 359-372. DOI: 10.1007/s10530-008-9253-y

Gerovasileiou, V., Akel, E., Akyol, O., Alongi, G., Azevedo, F., Babali, N., Bakiu, R., Bariche, M., Bennoui, A., Castriota, L., Chintiroglou, C., Crocetta, F., Deidun, A., Galinou-Mitsoudi, S., Giovos, I., Gökoğlu, M., Golemaj, A., Hadjioannou, L., Hartingerova, J., Insacco, G., Katsanevakis, S., Kleitou, P., Korun, J., Lipej, L., Michailidis, N., Mouzai Tifoura, A., Ovalis, P., Petović, S., Piraino, S., Rizkalla, S., Rousou, M., Savva, I., Şen, H., Spinelli, A., Vougioukalou, K., Xharahi, E., Zava, B., \& Zenetos, A. (2017). New Mediterranean Biodiversity Records (July 2017). Mediterranean Marine Science, 18(2), 355-384. DOI: $10.12681 / \mathrm{mms} .13771$

Glasby, T.M. \& Connell, S.D. (2001). Orientation and position of substrata have large effects on epibiotic assemblages. Marine Ecology Progress Series, 214, 127-135. DOI:10.3354/meps214127

Gray, J.E. (1867). Notes on the Arrangement of Sponges, with the Descriptions of some New Genera. Proceedings of the Zoological Society of London, 2, 492-558

Guardiola, M., Frotscher, J. \& Uriz, M.J. (2011). Genetic structure and differentiation at a short-time scale of the introduced calcarean sponge Paraleucilla magna to the western Mediterranean. Hydrobiologia 687: 7184. DOI: 10.1007/s10750-011-0948-1

Guardiola, M., Frotscher, J., \& Uriz, M. J. (2016). High genetic diversity, phenotypic plasticity, and invasive potential of a recently introduced calcareous sponge, fast spreading across the Atlanto-Mediterranean basin. Marine biology, 163(5), 123. DOI: 10.1007/s00227-016-2862-6 
Haeckel, E. (1870). Prodromus eines Systems der Kalkschwämme. Jenaische Zeitschrift für Medicin und Naturwissenschaft 5, 236-254 (also appeared in English as: Haeckel, E. 1870. Prodromus of a system of the Calcareous sponges. Annals and Magazine of Natural History, 5:176-191. DOI: 10.1080/00222937008696137

Haeckel, E. (1872). Die Kalkschwämme: eine Monographie: in zwei Bänden. Text und einem Atlas mit 60 Tafeln Abbildungen. Biologie der Kalkschwämme Reimer, (1-2. 1, 484 pp, 2, pp. 418). Berlin.

Keller, C. (1889). Die Spongienfauna des rothen Meeres (I. Hälfte). Z wiss Zool $48,311-405$.

Klautau, M. \& Valentine, C. (2003). Revision of the genus Clathrina (Porifera, Calcarea). Zeitschrift für Wissenschaftliche Zoologie, 139(1), 1-62. DOI: 10.1046/j.0024-4082.2003.00063.x

Klautau, M., Monteiro, L. \& Borojevic, R. (2004). First occurrence of the genus Paraleucilla (Calcarea, Porifera) in the Atlantic Ocean: $P$. magna sp. nov., Zootaxa, 710, 1-8. DOI: 10.5281/zenodo.158320

Klautau, M., Imešek, M., Azevedo, F., Pleše, B., Nikolić, V. \& Ćetković, H. (2016). Adriatic calcarean sponges (Porifera, Calcarea), with the description of six new species and a richness analysis. European Journal of Taxonomy, 178, 1-52. DOI: 10.5852/ejt.2016.178

Lamarck, J.B.M. (1815). Suite des polypiers empâtés. Mémoires du Musée royal d'histoire naturelle, 1, 69-80, 162-168, 331-340.

Lamarck J.B.M. (1819). Histoire naturelle des animaux sans vertèbres. Tome sixième, 1re partie. (vi, pp. 343). Available from, http://www.biodiversitylibrary.org/item/47441

Longo, C. \& Pronzato, R. (2011). Class Calcarea. In: Pansini M., Manconi R. \& Pronzato R. (Eds) Fauna d'Italia - Porifera I - Calcarea, Demospongiae (partim) Hexactinellida, Homoscleromorpha. (pp. 117-244). Bologna, Calderini.

Longo, C., Mastrototaro, F. \& Corriero, G. (2007). Occurrence of Paraleucilla magna (Porifera: Calcarea) in the Mediterranean Sea. Journal of the Marine Biological Association of the UK 87, 1749-1755. DOI:10.1017/s0025315407057748

Mačić, V., Petović, S. (2016) New data on the distribution of the alien sponge Paraleucilla magna Klautau, Monteiro \& Borojević, 2004 in the Adriatic Sea. Studia Marina 29(1): 63-68.

Manconi, R., Cadeddu, B., Ledda, F. \& Pronzato, R. (2013). An overview of the Mediterranean cave-dwelling horny sponges (Porifera, Demospongiae). ZooKeys, 281, 1-68. DOI: 10.3897/zookeys.281.4171

Montagu, G. (1814). An Essay on Sponges, with Descriptions of all the Species that have been discovered on the Coast of Great Britain. Memoirs of the Wernerian Natural History Society. 2, 67-122, pls III-XVI.

Ostroumoff, A. (1894). Further contributions to the natural history of the Bosphorus. Zapisok Imperatorskoy Akademii Nauk, St. Petersburg, Supplement to, 74(5), 1-46.

Ostroumoff, A. (1896). Otchet o dragirovkax i planktonnyix ulovax ekspeditsii "Selyanika". Bull Acad Imp Sci Saint Petersb, 5, 33-92.

Paulay, G., Kirkendale, L., Lambert, G. \& Meyer, C. (2002). Anthropogenic biotic interchange in a coral reef ecosystem: a case study from Guam. Pacific Science, 56, 403-422. DOI: 10.1353/psc.2002.0036

Perçin, F. (2018). Bir Balikçi Barinaği Çalişma Alani Risk Faktörleri: Izmir lli Örneği. Ziraat Mühendisliği, (366), 28-38. DOI: 10.33724/zm.505580

Rapp, H. T. (2013). A monograph of the calcareous sponges (Porifera, Calcarea) of Greenland. Journal of the Marine Biological Association of the United Kingdom, 95, 1395-1459. DOI: 10.1017/S0025315413001070

Ridley, S.O. (1884). Spongiida. Report on the Zoological Collections made in the Indo-Pacific Ocean during the Voyage of H.M.S. 'Alert', 2, 366-482.

Row, R.W.H. (1911). Reports on the Marine Biology of the Sudanese Red Sea, from Collections made by Cyril Crossland, M.A., B.Sc., F.Z.S. XIX. Report on the Sponges collected by Mr. Cyril Crossland in 1904-5. Part II. NonCalcarea. Journal of the Linnean Society. Zoology, 31(208), 287-400. DOI: 10.1111/j.1096-3642.1911.tb00461.x

Schmidt, O. (1862). Die Spongien des adriatischen Meeres. Wilhelm Engelmann, i-viii, 1-88.
Sghaier, Y. R., Zakhama-Sraieb, R., Hmida, A. B., \& Charfi, F. (2019). An inventory of non-indigenous species (NIS) inside and outside three tourist marinas from the southern Mediterranean coast. Journal of the Black Sea/Mediterranean Environment, 25(1).

Sollas, W.J. (1885). A Classification of the Sponges. Annals and Magazine of Natural History, 16, 395. DOI: 10.1080/00222938509459901

Topaloğlu, B. \& Evcen, A. (2014). Updated checklist of sponges (Porifera) along the coasts of Turkey. Turkish Journal of Zoology, 38, 665-676. DOI: 10.3906/zoo-1405-79

Topaloğlu, B., Evcen, A. \& Çinar, M. E. (2016). Sponge Fauna in the Sea of Marmara. Turkish Journal of Fisheries and Aquatic Sciences, 16, 51-59. DOI: 10.4194/1303-2712-v16_1_06

Tsurnamal, M. (1969). Sponges of Red Sea origin on the Mediterranean coast of Israel. Israel Journal of Zoology, 18, 149-155.

Tsurnamal, M. (1975). The calcareous sponges of shallow habitats along the Mediterranean Coast of Israel. Israel Journal of Zoology, 24, 137-153.

Ulman, A., Ferrario, J., Occhpinti-Ambrogi, A., Arvanitidis, C., Bandi, A., Bertolino, M., Bogi, C., Chatzigeorgiou, G., Çiçek, B.A., Deidun, A., Ramos-Esplá, A., Koçak, C., Lorenti, M., Martinez-Laiz, G., Merlo, G., Princisgh, E., Scribano, G. \& Marchini, A. (2017). A massive update of non-indigenous species records in Mediterranean marinas. A massive update of non-indigenous species records in Mediterranean marinas. Peer Journal, 5, e3954. DOI: 10.7717/peerj.3954

Vacelet, J., Bitar, G., Carteron, S., Zibrowius, H. \& Perez, T. (2007). Five new sponge species (Porifera: Demospongiae) of subtropical or tropical affinities from the coast of Lebanon (eastern Mediterranean). Journal of the Marine Biological Association of the UK, 87 (6), 1539-1552. DOI: $10.1017 / \mathrm{S} 0025315407060687$

Van Soest, R.W.M., Boury-Esnault, N., Hooper, J.N.A., Rützler, K., de Voogd, N.J., Alvarez, B., Hajdu, E.; Pisera, A.B., Manconi, R., Schönberg, C., Klautau, M., Kelly, M.; Vacelet, J., Dohrmann, M., Díaz, M.-C., Cárdenas, P., Carballo, J.L., Ríos, P., Downey, R., Morrow, C.C. (2020). World Porifera Database. Accessed at http://www.marinespecies.org/porifera on 2017-02-01. DOI: 10.14284/359

Van Soest, R.W.M., Picton, B.E. \& Morrow, C. (2017b). Sponges of the North East Atlantic. In: World Biodiversity Database CD-ROM Series, Windows/Mac version 1.0. (ETI, University of Amsterdam: Amsterdam). Available from http://speciesidentification.org/index.php?groep=Sponges\&selectie=15\& hoofdgroepen_pad=\%2C1\%2C15 (accessed 01.February.2017).

Zammit, P.P., Longo, C. \& Schembri, P.J. (2009). Occurrence of Paraleucilla magna Klautau et al., 2004 (Porifera: Calcarea) in Malta. Mediterranean Marine Science, 10, 135-138. DOI: 10.12681/mms.114

Zenetos, A., Gofas, S., Verlaque, M., Çinar, M. E., Raso, J. G., Bianchi, C. N. \& Siokou, I. (2010). Alien species in the Mediterranean Sea by 2010. A contribution to the application of European Union's Marine Strategy Framework Directive (MSFD). Part I. Spatial distribution. Mediterranean marine science,11(2), 381. DOI: 10.12681/mms.87

Zenetos, A., Gofas, S., Verlaque, M., Çinar, M., Garcia Raso, J., Bianchi, C. \& Streftaris, N. (2011). Alien species in the Mediterranean Sea by 2010. A contribution to the application of European Union's Marine Strategy Framework Directive (MSFD). Part I. Spatial distribution. Mediterranean Marine Science, 12(2), 509. DOI: $10.12681 / \mathrm{mms} .49$

Zenetos, A., Gofas, S., Morri, C., Rosso, A., Violanti, D., Raso, J. G. \& Verlaque, M. (2012). Alien species in the Mediterranean Sea by 2012. A contribution to the application of European Union's Marine Strategy Framework Directive (MSFD). Part 2. Introduction trends and pathways. Mediterranean Marine Science, 13, 328-352. DOI: 10.12681/mms.327

Zenetos, A., Çinar, M. E., Crocetta, F., Golani, D., Rosso, A., Servello, G. \& Verlaque, M. (2017). Uncertainties and validation of alien species catalogues: The Mediterranean as an example. Estuarine, Coastal and Shelf Science, 191, 171-187. DOI: 10.1016/j.ecss.2017.03.031

Zibrowius, H. (2002). Assessing scale and impact of ship-transported alien fauna in the Mediterranean? In: CIESM Workshop Monographs, Vol. 20, pp. 6 